\title{
'Yusuf Neyyir Adında Biri' Gülzâr-1 Hayâl Kitabı
}

(Hayatı/Eserleri-İnceleme-Metin)

Canan OLPAK KOÇ 


\title{
(C) Copyright 2021
}

Bu kitabın, basım, yayın ve satış hakları Akademisyen Kitabevi A.Ş.'ne aittir. Anılan kuruluşun izni alınmadan kitabın tümü ya da bölümleri mekanik, elektronik, fotokopi, manyetik kağıt ve/veya başka yöntemlerle çoğaltılamaz, basılamaz, dağıtılamaz. Tablo, şekil ve grafikler izin alınmadan, ticari amaçh kullanlamaz. Bu kitap T.C. Kültür ve Turizm Bakanlı̆̆ bandrolü ile satılmaktadır.

ISBN

978-625-7707-75-6

Kitap Adı

'Yusuf Neyyir Adında Biri’ ve Gülzâr-1 Hayâl Kitabı

(Hayatı/Eserleri-İnceleme-Metin)

\author{
Yazar \\ Canan Olpak Koç \\ Yayın Koordinatörü \\ Yasin Dilmen \\ Sayfa Tasarımı \\ Akademisyen Dizgi Ünitesi \\ Yayınc1 Sertifika No \\ 47518 \\ Baskı ve Cilt \\ Vadi Matbaacılık \\ Bisac Code \\ FIC019000
}

\section{GENEL DAĞITIM}

Akademisyen Kitabevi A.Ş.

Halk Sokak 5 / A

Yenişehir / Ankara

Tel: o312 4311633

siparis@akademisyen.com

\section{www.akademisyen.com}




\section{ÖN SÖZ \\ 'YUSUF NEYYİR ADINDA BİRI'}

Cevdet Kudret, Tanzimat'tan Meşrutiyete Türk Roman ve Hikâyesi hakkında genel bilgiler verdiği çalışmasında, Müsameretname yazarı Emin Nihat’tan söz ederken şu ifadeleri kullanır:

"Emin Nihat'ın hayatı üzerine, bir tek kaynak dışında, hiçbir bilgi yoktur. Daire arkadaşı olduğu anlaşılan Yusuf Neyyir adında birinin Gülzâr-1 Hayâl (1288/kapakta 1289 "1872/1873”) adlı hikâyesinin başına yazdığı bir "takriz"in sunuluşundan, onun "mektûbî-i hâriciye hulefasından" olduğu öğrenilmektedir (Kudret, 1968: 58).

Son zamanlara dek Emin Nihat merkezli çeşitli çalışmalarda da atıf yapılan bu cümlelerde ${ }^{1}$ acı olan, sadece modern Türk hikâyeciliğinin öncülerinden Emin Nihat hakkında oldukça sınırlı bilginin olması değildir. Kaldı ki Selim İleri, Emin Nihat hakkında daha kapsayıcı bilgiler yayımlayarak edebiyat tarihimizin bu yöndeki eksikliklerini bir nebze olsun gidermiştir. Asıl acı olan, 'Yusuf Neyyir adlı biri' ifadesidir. Türk edebiyatında geleneksel anlatıdan modern anlatıya geçişin ilk temsilcilerinden Yusuf Neyyir; ölümünün üzerinden - Cevdet Kudret'in çalışmasının ilk kez 1965’te yayımlandığ düşünüldüğünde- seksen beş yıl geçmesine rağmen hâlâ 'biri' olmaktan öteye gidememiştir.

Burada Cevdet Kudret'i eleştirmiyoruz. Sonuçta o, Yusuf Neyyir hakkında, eldeki sınırlı bilgilerden hareketle 'biri' ifadesini kullanmıştır. Eleştirilmesi gerekenler, başta basın ve edebiyat dünyasının Yusuf Neyyir'le çağdaş isimleri olmak üzere, Ney-

Salih Okumuş, Emin Nihat üzerine hazırladığı çalışmada şu ifadeleri kullanır: "Emin Nihat Bey'in hayatı hakkında bir tek kaynak dışında hiçbir bilgiye sahip değiliz. Elimizde, daire arkadaşı olduğu anlaşılan Yusuf Neyyir adında birinin "Gülzâr-1 Hayâl" (1289/"1873") adlı hikâyesinin başına yazdığı "takriz" mevcuttur." (Okumuş, 1999: 215) Okumuş'un da 'Yusuf Neyyir adında biri' ifadesini kullanması ilginç bir tesadüftür. 
yir'in erken ölümünün hemen peşinden edebiyat tarihi alanında eserler vermeye başlamış isimlerdir. Bir sonraki neslin, Tanzimat nesline genelleyici olumsuz yaklaşımı olduğu kadar, ailesinin de sanatçıya sahip çıkmaması eleştirilmesi gereken yaklaşımlardandır. Sonuçta Selim İleri, Emin Nihat hakkında kapsayıcı bilgilere Emin Nihat'ın oğlu Arif Paşa’nın babasına dair yazdığı bilgilerden yola çıkarak ulaşmıştır. Yusuf Neyyir'in büyük bir tiyatro sanatçısı olan oğlu Burhan Tepsi'yse, kendi hatıratını yayınlamış olmasına karşın bu hatıratta babasına çok az -ve onda da yüzeysel bilgilerle- değinmiştir.

Yusuf Neyyir, edebiyat tarihinde, onun açtı̆̆ 1 üslup çizgisinde yürüyen başka sanatçıları yetiştirmiş bir yazar sayılmaz. Ne herhangi bir türün en başat örneklerinden birini vermiştir ne de başlı başına bir akımın kapılarını aralamıştır. Öte yandan otuz sekiz yıllık ömründe, Türk anlatısının Batılı metinlerle ilk temas anında eserler vermiş olmasıyla öylesine 'biri' sayılmayı hak etmeyecek bir isimdir.

Nietzsche’nin büyük oranda temsili karakteri Zerdüşt, "Beni anlamıyorlar; ben bu kulakların dinleyeceği ağız değilim." (Nietzsche, 2018: 12) demişti. Ama iyi metinlerin unutulmayacağını, üzerinden ne kadar zaman geçerse geçsin birgün ortaya çıacağını geçmişin birçok tecrübelerinden biliyoruz: Ölümünden çok sonra kıymeti bilinen Edgar Allan Poe, Herman Melville'nin 1953’ye yayımlanıp değeri ancak 20. yüzyılda anlaşılan Katip Bartleby'si, ölümü -onda da birkaç satırdan ibaret olmak kaydıyla- yerel bir gazete dişında kimsenin dikkatini çekmediği Kafka; Kürk Mantolu Madonna'yla çok satanlar listesine ölümünün üzerinden yaklaşık yetmiş yıl sonra girecek Sabahattin Ali, Saatleri Ayarlama Enstitüsü̉nün ikinci baskısının 26 yıl geçince ancak yapılabildiği Ahmet Hamdi Tanpınar, onu yakından tanıyanların bile Tutunamayanlar romanından habersiz olduğu Oğuz Atay... Eserlerinin gücüyle zamanın unutkan hafızasında teslim olmayan büyük kalemlerden bazılarıdır. 
Edebiyat tarihinin hatırlamadığı, zamanın hafızasınınsa unutmayı tercih ettiği Yusuf Neyyir'in, "iyi metinler"yle birgün yeniden ortaya çıkacağını söylemek zorlama bir iyi niyet olacaktır. Fakat eşiklerin belirlendiği, tarihin olmasa bile kültürlerin kırılma noktasına geldiği, kapıların aralandığ hatta ondan öte bu belirmeye, kırılmaya, aralamaya hizmet etmiş öncü metinler; yeniden konuşabilmek için "iyi metin” olup olmadıklarına göre değerlendirilmemelidir. Nasıl ki maraton koşucularını ayağa kaldıran bebekliklerinde attıkları ilk adımlarıysa ve bugün dünya edebiyatı seviyesinde bir Türk edebiyatından söz edebiliyorsak işte o seviyenin başlangıç yeri Yusuf Neyyir gibi öncü kalemlerdi. Hâliyle Yusuf Neyyir, belki “iyi metinler” üretememişti, belki otuz sekiz yıllık ömrü, sahibinin o "iyi metne" ulaşmasına müsaade etmemişti fakat öncü kimliğiyle, "biri” kabul edilmenin çok ötesine çoktan geçmeliydi.

$\mathrm{Bu}$ iyi niyetlerle beş yıl önce başladığım çalışma kaynak bulmanın zorluğu nedeniyle yayımlamakta sabırlı davranmayı gerektirmiştir. Hem yazar hem de eseri hakkında çok az, onlar arasında da ciddi eksikler ve tutarsızlıkların olduğu, çalışma vardır. Öncelikle metin üzerinde dikkatli bir okuma yapmaya gayret ederek Osmanlı Türkçesinden çeviri tamamlandı. Günümüz Türkçesiyle yayınlanmadan önce orijinal haliyle yayınlanmasının daha uygun olacağı düşünülerek bu hâli inceleme-metin kitabına eklendi. Metnin öncesinde Yusuf Neyyir'in hayatı ve eserleri hakkında bilgi verildi.

Çalışmam süresince desteğini esirgemeyen Prof. Dr. Abide Doğan'a, Prof. Dr. Aliye Uslu Üstten'e ve zaman zaman sorularımla vaktini çaldığım Dr. Kayahan Özgül'e teşekkür ederim. 
"İnsân insân mıdır ki kendisine akl isnâd etsin de Cenâb'ı Rabb'i Zülcelâl'in her ânda vahdâniyyet ve ebediyyetine kâil olmasın?” Yusuf Neyyir 


\section{İÇiNDEKILER}

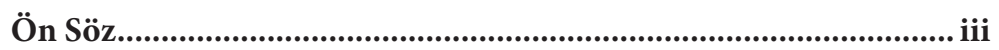

Yusuf Neyyir Hakkında ...........................................................................1

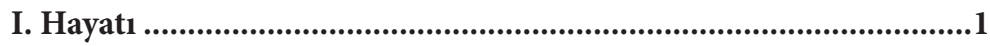

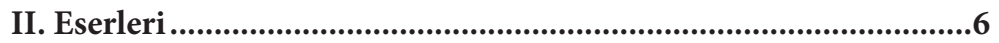

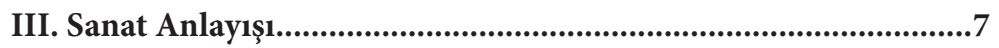

Gülzâr-1 Hayâl Kitabının İncelemesi................................................. 13

Gülzâr-1 Hayâl Metni.......................................................................... 37

Gülzâr-1 Hayâl Birinci Cilt ........................................................... 38

Gülzâr-1 Hayâl İkinci Cilt......................................................... 77

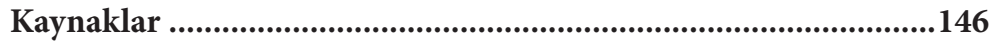

